\title{
A State of the art of flat-slab frame tests for gravity and lateral loading
}

\author{
by Dario Coronelli, Aurelio Muttoni, Ion Radu Pascu, Antonio Pinho Ramos, Teresa Netti
}

\begin{abstract}
This paper presents a critical review of the state of the art of experimental research concerning the seismic response of reinforced concrete flat slab frames. After a summary of tests on connections, the paper examines tests carried out on frames with gravity and cyclic lateral loading, and shake table tests; scaled specimens and one real scale study are included. A discussion of the results reached so far is provided focusing on the global response, the different load types and effects; the ultimate rotations at failure in relation to the gravity shear and a classification of different failure modes for different types of connections. Based on this analysis, the research needs are highlighted. An experimental program launched to address these open questions is described. Further open topics are highlighted.
\end{abstract}

Keywords: full-scale multi-story RC flat slab building, cyclic and dynamic lateral loading, testing, punching.

\section{Introduction}

Nowadays, reinforced concrete flat slabs supported on columns represent one of the most commonly used structural systems for the main buildings typologies (commercial, office, industrial, residential and parking garages). Their common use is due to both their simplicity to construct and to use. The simple formwork and reinforcement layout, together with a flat soffit allowing an easy placement of heating, ventilating, air-conditioning, lighting, sewers and water systems, are the features that characterised this building typology (Muttoni 2008). This structure does not require beams so this is an important advantage, however there is a drawback: the punching shear failure that can develop around columns due to a high shear stress concentration.

The European standard EN 1998-1 for seismic design of buildings does not include specific indications on flat slab design. However, in several European countries with a high seismic hazard, this solution is adopted for low-rise buildings. Fardis (2009) highlights the need to develop studies on flat slab systems so that "the cost-effectiveness and seismic performance of earthquake resistant concrete buildings will benefit from the rational use of flat slab frames as part of the lateral-load-resisting system (i.e. what is called in EN 1998-1 "primary seismic elements)".

The North American researches in this field provide a wide scientific literature and design rules for flat slabs which are mostly based on the results of experimental research and have been implemented in codes (ACI-ASCE committee 421, 2010; 2015). 
For flat slabs, the tests are of three typologies with the size of the specimen increasing from one type to the following: (i) isolated slab-column connections, (ii) single complete floors and (iii) complete frames consisting of at least two stories.

At present, many works on the behaviour of isolated slab column connection have already been published, fewer regarding a complete scaled size floor tested for cyclic loading (Hwang and Moehle, 1993, 2000; Rha et al., 2014;) and only three consisting of complete buildings (a fullscale test by Fick et al., 2017 with cyclic loading and two small scaled two-storey frames tested by Moehle and Diebold, (1984) and Kang and Wallace (2004) under seismic loads using a shake table).

The aim of this paper is to describe the state of the art of experimental research concerning the response of reinforced concrete flat slab frame tests for gravity and lateral loading, and to describe the main research needs in this field.

Due to the growing use of flat slab structures, there is a need for a greater and deeper knowledge of the behaviour of these elements as part of the whole system of the building, together with the requirement of a European regulation. For these needs, the Slab STRESS project was proposed within the SERA programme (http://www.sera-eu.org). Flat slab floors in a real scale flat slab building will be tested for seismic and cyclic loading at the reaction wall facility of the JRC in the ELSA laboratory in Ispra (VA, Italy). The results will provide the basis for a design procedure based on the deformation capacity assessment.

This paper is structured as follows. The second section presents the experimental works divided in three different groups: tests on isolated slab-column connections, on single floors and on multi-storey frames with quasi-static or dynamic shaking table tests. The results of tests of isolated connection studies are briefly summarized, but not further discussed in the following sections because the aim of this paper is to describe the state of the art for flat slab frames. In the third section, the design of the specimens is discussed. The experimental setups are described in the fourth section. Then a summary and discussion of the main results obtained during the tests are reported in the fifth section. The main research needs are discussed in the sixth section: the behaviour of the whole full-scale system, realistic boundary conditions, the redistribution of internal forces with progressive failures, size effect and the use of transverse reinforcement. The Slab STRESS experiment is described in the seventh section. The last section provides a summary of the analysed works and of the conclusions drawn.

\section{Experimental studies}

Space and equipment limitations in the laboratory often determine the size of the tests specimens. For this reason, many works on the behaviour of isolated slab column connections have already been done, fewer regarding a single storey or multi storey frames.

\subsection{Isolated slab-column connections}

Since flat slab frames are vulnerable to brittle punching shear failures in the slab-column connection, many studies focused on the behaviour and design of internal connections under combined gravity and lateral loading (Hawkins and Mitchell 1979; Pan and Moehle 1987; Megally and Ghali (2000); Robertson et al. 2002; Dovich and Wight 2005; Kang and Wallace 2006; Hueste et al., 2007; Tian et al., 2008; Drakatos et al.; 2016, Almeida et al. 2019, Setiawan et al., 2019 amongst many others). 
As a summary, the tests show the different failure modes and the dependence of the ultimate drift capacity on the gravity shear ratio (defined here as ratio between the acting vertical shear force and the punching shear resistance according to $\mathrm{ACl}$ 318-14): larger gravity shear ratios imply lower horizontal deformation capability (horizontal drift). Larger horizontal drift ratios are possible when shear reinforcement is used; also the presence of fibre-reinforced concrete in the slab-column connection region is effective in increasing the deformation capacity of slabcolumn connections.

The tests of the component in the form of isolated connection subassembly have the drawback that the boundary conditions may not accurately represent the actual moment distribution and the redistribution in multi bay slab column frames due to non-linear behaviour (Einpaul et al. $2015,2016)$. Several tests have been carried out on scaled specimens, thus leaving the sizeeffect which can be demonstrated theoretically (Drakatos et al., 2018) to be investigated. Tests on internal joints are numerous but fewer results are available for edge or corner columns.

\subsection{Flat slab floors}

A description of the specimens for each study is given below. The geometry is shown in Fig. 1 and Tables 1 and 2. Both the prototype structures and the scaled specimens are considered, for all but the only full-scale study. Table 3 reports the calculation of gravity shear ratios, using the information gathered from the publications, the comparison with the values given by the Authors; these will be discussed at the end of this section.

Hwang and Moehle $(1993,2000)$ tested a slab specimen constructed at $40 \%$ of a full-scale floor. Four different column geometries were chosen to collect data related to the effects of column regularity, and the reinforcement layout was varied in the slab-column connections. The authors report a gravity shear ratio (GSR) of 0.3 for all column positions.

Rha et al. (2014) present an experimental programme on five two-way continuous flat plate floors, approximately half scale of the prototype structure. The gravity shear ratio reported was $0.21,0.28$ and 0.44 for corner, lateral and internal columns, respectively.

The specimens tested in these two studies have rectangular panels with similar spans and interior columns sizes (Fig.1).

\subsection{Flat slab multi-storey frames}

Fick et al., (2017) studied a full-scale three-story, two-bay in the load direction, reinforced concrete flat-plate frame designed to resist gravity loading (Fig.2). The overall slab dimensions were $9.1 \times 15.2 \mathrm{~m}$ and thickness is $180 \mathrm{~mm}$. Support was provided by six $460 \mathrm{~mm}$ square columns spaced at $6.1 \mathrm{~m}$ in both directions. Overhangs measuring $1.5 \mathrm{~m}$ were provided along the whole perimeter. The tested structure had a height of $9.1 \mathrm{~m}$ above the footings, each story measuring $3.0 \mathrm{~m}$. Despite the fact that a gravity shear ratio of 0.21 was reported, a distinction should be made between edge and corner columns, since the tributary areas are different.

Moehle and Diebold, (1984) studied a two-story reinforced concrete flat-plate system built at three-tenths of the dimensions of a typical structure (Fig.3a). The test was conducted on a shaking table. A shallow beam (137 mm wide and $107 \mathrm{~mm}$ deep) was provided along the two edges perpendicular to the test direction and the slab had lateral overhangs on the other sides. The gravity shear ratio was not reported. 
Kang and Wallace (2005) conducted shaking table tests on a conventional reinforced-concrete (RC) two storey, flat plate frame (Fig.3b) and a post-tensioned (PT) slab-column frame incorporating shear reinforcement. Shear reinforcement for the RC and PT specimens consisted of stud-rails satisfying requirements of $\mathrm{ACl} 318-02$ and $\mathrm{ACl} 421.1 \mathrm{R}-99$. Due to dimensional limitations of the shaking table, a scale factor of approximately $1 / 3$ of typical buildings was used for both specimens (RC and PT), resulting in a relatively thin slab (89 mm and $73 \mathrm{~mm}$, respectively). The gravity shear ratio reported for the RC specimen was 0.25 for internal columns and 0.20 for edge columns.

It has to be noted that the geometry of the different tests presents several differences. All specimens but one are scaled to $30-50 \%$ of the prototype. Panels are either square or rectangular. One test considers edge beams orthogonal to the loading direction. Three tests include overhangs on two or four sides of the slab which determines a particular configuration with connections that can be considered as internal if the portion of the slab surrounding the column is sufficiently large (Park and Gamble, 2000).

Span to depth ratios are in the range 30-35 with the exception of one test with a ratio equal to 24. The size of the columns relative to the span ranges from $1 / 10$ to $1 / 13$. Most tests had square columns, one test varied the proportions of the column sizes and had different internal, lateral and corner columns.

Testing floors with column portions above and/or below the slab determines a structural scheme that differs from that of a multi-story frame.

Comparing the geometry of the different tests in Table 1, the scaled specimens can be grouped in similar couples: the two quasi-static campaigns by Hwang and Moehle and Rha et al; the two shaking table tests by Moehle and Diebold and Kang and Wallace. This allows for a comparison of the effects of other parameters and aspects of the tests, related to the number of spans, loading history, slab thickness, reinforcement details, shear reinforcement, etc. The full-size specimen geometry stands out of the group due to its proportions; it can be compared with the prototype structures of two scaled specimens with equal span dimensions.

\section{Prototype structures and specimen design}

The specimen designs are typically obtained by scaling down prototype buildings (Table 4). The design of the latter (Tables 5 and 6 ) is described in this section. In the following, a primary element or system is defined as providing seismic resistance in a structure whereas secondary (also called non-participating) elements are considered as capable of carrying primarily gravity loads concurrently with the imposed deformations related to the lateral actions.

Hwang and Moehle. The prototype structure was a high-rise building with non-participating slabs. The RC flat-plate frame was designed in accordance with ACI 318-83 to carry combined gravity and lateral loads (wind dominating over seismic) where the effects of both actions have been considered in the design. The gravity load effects were calculated using the Direct Design method moments ( $\mathrm{ACl} 318-83$ ). The lateral load effects were analysed using a frame model considering only the column strip, increasing steel reinforcement by $50 \%$ with respect to that required by gravity loads. In half of the slab, moment redistribution was considered, reducing the top layer steel at supports by up to $1 / 3$. Integrity reinforcement according to ACI-ASCE 352 (1988) was provided. The column design complied with seismic design of such members in zones of moderate seismic risk. 
Rha et al. state that their prototype was a multiple bay slab column frame. The slab reinforcement for the scaled specimens considered three different cases (S1, S2, and S3). The former corresponds to gravity loads only and was used for two specimens which are out of the scope of this paper since they were tested with only vertical loads. The second and third had a higher top steel ratio at the support in the column strip and were used for the specimens tested with lateral loading as well; the third had also additional continuous bottom bars at each connection.

Fick et al. Only gravity design was carried out for the slab, using the Direct Method according to $\mathrm{ACl} 318$ (2002). This choice aimed at studying the performance of existing structures designed following this approach despite the fact that they are located in seismic regions.

Moehle and Diebold. The prototype structure was a primary slab frame for Zone 2 according to UBC 1982 and designed to support combined gravity and seismic loads with ACI 318-83. The direct design method was used to determine the moments due to gravity-loads. The lateral load effects were analysed using a frame model considering only the column strip. Load combinations showed that the design of the slab was controlled by the gravity loads, though the seismic combination produced comparable maximum values of internal moments in the slab.

Kang and Wallace. The research considered as prototype structures for the two specimens representing secondary slab frames for buildings with primary walls or frames. The prototype was designed according to $\mathrm{ACl} 318-02$ for Zone 4 (high) seismic region. The authors state that these can be considered either non-participating in high seismic risk regions or intermediate frames in moderate seismic regions. The design aimed at complete longitudinal reinforcement yielding before punching. Strong column design enforced the nonlinear behaviour in the slab. Stud shear reinforcement was placed in cross layout $(\mathrm{ACl} 421.1 \mathrm{R}, 1999)$ spaced at $0.5 \mathrm{~d}=35$ $\mathrm{mm}$, extending $4 \mathrm{~d}$ from the column face to prevent failure outside the shear reinforced zone.

It has to be noted that the design of all specimens was based on the North American codes. Punching shear verifications were carried out using the ACl 318 models (1983-2002).

All specimens but one considered lateral actions in the design. Amongst these, the flat slab frames are either non-participating frames part of systems for high seismicity zones or in one case primary intermediate frames in a moderate seismicity zone.

Fick et al. carried out gravity load design, without lateral load resisting elements. One interesting issue is that the spans and column sizes of this real-size test correspond to those of the prototype of one of the two scaled models for shaking table tests. Hence, a comparison is possible of the lateral loads effects in systems with or without a seismic design.

Column design was carried out by Moehle and Diebold and Kang and Wallace in order to avoid column yielding, concentrating inelastic deformations in the slab.

\section{Testing}

\subsection{Test setup}

Hwang and Moehle. This is the only study with biaxial lateral loading. The lateral load was transferred to the slab by a perimeter steel frame, with compression forces on alternate sides 
in each orthogonal direction. The column portions beneath the slab developed shear and moment. A biaxial cyclic displacement history with increasing amplitude was imposed, with lateral drifts from $0.25 \%$ to $4 \%$. The load protocol imposed two cycles in one direction, followed by two in the orthogonal direction. The gravity loads consisted of the slab weight and additional lead blocks distributed on the upper surface.

Rha et al. Two different loading typologies and histories were imposed (lateral monotonic LM and lateral cyclic LC). The gravity loading for lateral loading tests was imposed by concrete blocks piled on the slab top surface. The slab had half-column members above and below; the load was transferred by a steel frame linking the column tops to an actuator (supported independently in order not to bear its weight on the columns).

Fick et al. The gravity load, rather limited, was applied by tall bins filed with water. The lateral load was transferred by steel framing connected to the sides of the slab floors at the centreline. The structure was tested to failure under cycles of increasing quasi-static lateral displacement imposed at the third top floor, with forces acting on the other floors controlled to vary linearly with height.

Moehle and Diebold. The gravity loading, defined in order to produce the correct magnitude of slab moments and shears, was obtained adding lead blocks on the slab surface. The structure was tested with eleven base motions of successively increasing intensity from $0.012 \mathrm{~g}$ to $0.83 \mathrm{~g}$ lateral acceleration. The acceleration histories recorded during the 1940 Imperial Valley earthquake were used for the test. The action was both lateral and vertical in four runs.

Kang and Wallace. Weights were added on the slab surface for inertia, controlling the gravity shear ratio to correspond to the prototype design. The ground motion of the September 21, 1999, earthquake in Taiwan (long duration) was selected. The signal was scaled to obtain five subsequent runs with maximum lateral accelerations from $0.11 \mathrm{~g}$ to $1.25 \mathrm{~g}$. The action was lateral along one direction.

For these experimental works, the distribution of gravity loads on the slab in the different cases was in some cases uniform, in others more concentrated or irregular, depending on the use of lead weights, barrels filled with water or concrete blocks piled on the slab surface.

Transfer of the lateral forces to the specimen occurred either loading the columns or the slab (in the latter case in different position - front and back or sides, with respect to the loading direction). In the case where several points were used to transfer loads, the relative stiffness of members in a system plays a role.

In multi-storey quasi-static tests, a choice needs to be made on the force distribution (e.g. linear distribution).

Differences can be noted of testing one floor with columns beneath the slab and lateral loading on the floor (a scheme corresponding to a roof slab), or one floor with column beneath and above, loading the top of the columns (corresponding to an inter-story slab); a multistorey frame includes obviously both inter-story and roof slabs. According to the loading scheme and the structures geometry, the moment is transferred to the slab either by one or two columns framing into the connection, with a different stiffness and resistance of these vertical members relative to the slab, causing a different response of the connection. 


\subsection{Instrumentation}

The instruments used and quantities measured are summarised in Table 7. Some issues are highlighted below.

Hwang and Moehle. The measurements included the three force components of the reaction forces at the lower end of each column (all columns were pinned at their base). Hence, momentdrift relations for the joints could be determined in addition to the global response. The occurrence of punching was then determined based on observations of cracking during the test and post-processing joint moment-rotation diagrams.

Rha et al. The lateral forces were measured at the top of each column, while the vertical reactions at the bottom, using respectively horizontal and vertical load cells in the two locations. Lateral force-drift diagrams are given for each column, and the vertical force readings at the column bases for gravity loading and at failure were provided.

Fick et al. measured the lateral force - drift relations for the three stories. The extent of cracking in the connections and the columns in particular is reported.

Moehle and Diebold measured foundation shear and moment using transducers at the column bases; the dynamic response was recorded with accelerations and displacements; slab and column reinforcement strains were measured at selected locations. The damage was reported photographically and by visual observation (manual reporting on paper for the crack pattern in the slab at each floor level and columns).

Kang and Wallace. Triaxial load cells measured reactions at the column bases. The global response was studied with story shear and overturning moments, floor displacements and accelerations. For the local joint response, slab and column reinforcement strains were used to obtain moments and curvatures in these members and to study punching failure. Strain gages were installed on the shear studs, but the results are not reported.

\section{Results}

Hwang and Moehle (2000)

The global response followed a first relatively stiff branch up to a drift of $0,5 \%$. After the drift of $1 \%$, the test slab displayed a relatively plastic response up to a drift of $4 \%$. It reached the ultimate drift with a maximum load in the first N-S cycle at $4 \%$, while the following first cycle at $4 \%$ in $\mathrm{E}-\mathrm{W}$ showed a drop of lateral load with respect to the previous cycle, followed by increasing strength deterioration.

The test setup allowed the measurement of the moment-drift relation for each connection. The response shows a progressive yielding in the response, as is typical of flat slab connection response (Pan and Moehle, 1989). The authors highlight a plastic branch in the cycle envelope curves approximately between $1 \%$ and $4 \%$ drift.

A distinction is made by Hwang and Moehle between joint resistance, i.e. reaching maximum unbalanced load, and punching failure that can occur at higher drift values and lower unbalanced moments. The resistance of the connections (maximum unbalanced moment) was reached first on the edges and corners in the $+/-2 \%$ drift cycles in the $\mathrm{N}-\mathrm{S}$ direction. The same 
occurred in the lateral and corner connections during the following $+/-2 \% \mathrm{E}-\mathrm{W}$ cycles, with three out of four of the internal connections reaching their resistance as well. The punching of several connections occurred in the $+/-4 \% \mathrm{E}-\mathrm{W}$ cycles, at drifts between $3.1 \%$ and $3.7 \%$. Both internal and edge connections punched, but only one in a corner.

Failure modes for both the lateral and internal punched connections showed the typical failure surface on the extrados around the column. Lateral connections showed wide torsion cracks on the sides of the slab at the connection with the column.

The reported gravity shear forces at the base of the columns just before punching failure correspond rather closely to values obtained by hand calculations (see Table 3 ). The vertical reactions at four internal columns along the whole cycles leading to punching of these connections are reported. There are variations on the occurrence of punching of the order of $10-25 \%$, with reductions where the failure occurs and increases in the other connections. Once most of the connections failed, the slab was still capable of supporting the gravity loads and the values of the shear forces were rather close to the initial values.

Rha et al. (2014)

The global maximum lateral load was reached for drifts between 4 and $6 \%$ for the three tests.

Two identical specimens were tested, one for monotonic (LM) and the other for cyclic (LC) lateral load up to the first punching failure followed by monotonic lateral loads respectively. The ultimate drift of the structure was close to $6 \%$ in both tests, the cyclic test reaching a lower maximum load. With cyclic loading, the internal joint was the first to punch at $1.5 \%$ drift, while the failure in this location with monotonic loading occurred at $5.5 \%$ drift. Some of the lateral joints failed in the cyclic test LC at drifts lower than in the monotonic test. Although the continuation of test LC after the first connection punching was carried out as a monotonic test, the reduction in the ultimate drift of the lateral joints can be explained as an effect of damage accumulation in the first part of this test.

In all tests, the response at large displacements showed a progressive sequence of joint failures at different drift levels, with one or groups of two or three joints failing together distanced by drifts increases of $1-2 \%$. The damage reported shows radial cracking around internal and lateral columns, and torsional cracking on the sides of the slab at corner columns.

The tests by Rha et al. showed the influence of different load protocols in the global response; the tests were carried out until all six connections failed; this occurred between $5 \%$ and $6 \%$ drift. For monotonic loading LM after reaching the maximum lateral load a small reduction of the load was observed before all connections reached failure. The cyclic test LC showed a sizeable reduction of lateral loading after the first punching failure at the internal column; the test was then continued with a monotonically increasing displacement, and the load increased until the last connections failed close to $6 \%$ drift.

Fick et al. (2017)

A linear response was observed during the first cycle up to a mean drift ratio of $0.2 \%$. Flexural cracks appeared in both first- and second-story columns during the second cycle of loading to a roof-drift ratio of $0.4 \%$. In the successive load cycles, the imposed drift increased and the nonlinear response also increased, with both slab and column cracking. During the tests, the structure suffered very limited damage until a roof drift ratio of $1.5 \%$ whereas at a roof drift ratio of $2.9 \%$ north, one of the internal slab-column connections reached failure due to punching in 
the third floor (at a story drift ratio level of 3.3\%). The test was not continued beyond the occurrence of the first punching failure. This was characterized by a wide punching crack perimeter on the outer surface extending from $2 \mathrm{~d}$ to $5 \mathrm{~d}$ around the column and with a separation of the crack surfaces ranging $5-20 \mathrm{~mm}$.

\section{Moehle and Diebold (1984)}

The structure did not develop significant non-linearity in the overall load displacement relationship until drifts reached approximately $1.5 \%$ of structure height, after which the structure displayed a relatively plastic response to lateral drifts exceeding $5 \%$ of structure height, without reaching collapse.

Regarding the connection response, cracking of the slab surface around the columns spread with the increasing intensity of the runs. After the last run, a column penetration of 1-2 mm was observed at the internal connection, indicating a possible incipient failure. The exterior slabcolumn-spandrel showed spalling of concrete of the beam at a lateral drift of $5.5 \%$ of specimen height. The exterior connections continued to support load at increasing drifts.

The second-floor slab damage was less severe than first-floor damage, apparently because the slab was stronger than the columns at the second-floor level, that suffered from evident cracking.

\section{Kang and Wallace (2004)}

Based on measured response, the RC specimen was subjected to a peak drift level of approximately $3.4 \%$ with some global strength deterioration beyond $2.5 \%$. Story shear versus inter-story displacements relations indicate that the inter-story drift capacities conditioned by punching failure range between $2.5 \%$ and $3.4 \%$ for the $\mathrm{RC}$ specimen.

Damage was more significant and more widely distributed in the joints of the RC structure than in the PT specimen.

Despite the fact that the use of slab shear reinforcement reduced the extent of damage, punching failures occurred at significantly lower drift ratios than expected. The Authors observed also that the reduced drift capacity might be due to loss of shear capacity at the column-slab interface (deterioration of the zone between the column and the first shear reinforcement unit), a phenomenon which was not observed in the quasi-static tests in the literature.

\section{Discussion}

All test programmes described show that the global response reaches rather high ultimate drift levels, in a range between 2.5 and $6 \%$. For the lower values, the test by Fick et al. was stopped at $2.9 \%$ roof drift, at the failure of the first connection; hence this is a lower bound of the ultimate drift capacity. The lowest value correspond to the test by Kang and Wallace (2.5-3\%), a shaking table test with shear reinforcement in the slab. This results differs from those obtained on slabcolumn connections, where higher ultimate drifts have been measured using shear reinforcement. It has to be observed that the span-to-slab thickness ratio was lower in this study than in all other cases. Only one test was carried out, hence more tests with shear reinforcement are needed. The tests in the remaining three studies (Hwang and Moehle, Rha et al., Moehle and Diebold) reached ultimate drifts ranging 4-6\%. 
In Hwang and Moehle's tests, the biaxial loading effect shows the difference of the drift at maximum load of $4 \%$ in one direction, and a lower drift around $2 \%$ in the following cycles in the orthogonal direction. On the other side, it is significant that $4 \%$ could be reached with GSR = 0.3 and cycles of progressively increasing amplitude in orthogonal directions. As this is the only study with such loading, more research should be needed in this field.

The deformations reached in some tests are due to column deformation and damage as well, partly related to the column design. Cracking in the columns is reported in particular by Fick et al. and Moehle and Diebold. In the real scale specimen by Fick et al. this can be attributed to the design for gravity loads only. Damage occurred also in the test by Mohele and Diebold using strong column design for lateral loading; it must be remarked that large drifts of $5 \%$ were reached. A similar design was used by Kang and Wallace; this test had more limited damage in the columns, that can be explained both by the design and the fact that the test reached lower maximum drifts around $3 \%$.

All tests but one (Fick et al.) are on scaled specimens. As also discussed in the following, this shows the need of full-scale tests to confirm the reported results.

As regards the vertical component of the seismic actions, only one test is reported (Moehle and Diebold, 1984). The effect was not evident, compared to other tests where only lateral actions were applied. This effect needs further examination.

The test results on scaled specimens show a series of punching failures for increasing drifts, for either cyclic or monotonic loading. In the tests by Rha et al. the different failures occurred progressively as the drift increased, whereas Hwang and Moehle report that the punching failures occurred for several connections nearly simultaneously. This result is not confirmed nor contradicted by the only real scale test that was not continued beyond the first failure.

The use of monotonic or cyclic loading influences the drift at failure reached by the connections. Rha et al. tested two identical specimens with these different load protocols, and report a first punching failure at $4 \%$ with monotonic loading, compared with first punching at $1.5 \%$ drift with cyclic loading.

The sequence of failures changes according to different tests and campaigns. As an example (Fig.4) in Rha et al, for the specimen loaded by cyclic loading, the first failure was in the internal connection whereas for Hwang and Moehle, the first connections to fail were on the edges of the floor. In both testing campaigns, one or more corner connections did not punch. For the failures following the first (Fig.5), the former test observed punching starting from $1 \%$ drift up to $6.5 \%$ drift with GSR values ranging 0.45 to 0.2 according to the position of the connection (Fig.5a), while in the latter test punching failures started at $2 \%$ drift and occurred in most cases between $3 \%$ and $4 \%$ with GSR=0.3 (Fig.5b).

The differences described in the previous paragraphs are visible in Fig.6a, resulting in a wide range of ultimate drift ratios between 1.5 and $6.5 \%$ for GSR between 0.2 and 0.35 . Fig.6a and $6 \mathrm{~b}$ compare the results obtained in the tests described in this paper (Fig.6a) with those of the database of isolated slab-column connections analysed by Ramos et al. (2017, Fig.6b). In both sets of results, for GSR between 0.2 and 0.35 the values of ultimate drift are in the range 1.5$6 \%$. The scatter can be attributed to other parameters amongst which the longitudinal reinforcement ratio, slab thickness and the loading protocol. 


\section{Research needs}

Due to the typical laboratory dimensions, it is difficult to study the behaviour of the whole fullscale system. In fact, there is only one full-scale study of a multi-storey frame reported in the literature and a limited number on scaled storey or multi-storey frames.

However, there are many tests on isolated slab-column connections, many of which at scaled dimensions, and most are on internal connections. Relevant information on flat slab behaviour has been drawn from these. Nevertheless, the following drawbacks must be considered:

1) the boundary conditions may not accurately represent actual internal force distribution taking place in multi bay slab column frames.

2) Redistributions of internal forces due to cracking and yielding of reinforcement which can have a significant effect on the behaviour of actual flat slabs (Einpaul et al. 2015, 2016), as well as the redistributions due to progressive deterioration of joints, cannot be investigated with tests on isolated slab-column connections.

3) In addition, the effect of compressive membrane action and size-effect are partly unexplored (Drakatos et al., 2018).

It is important to be able to compare the set of results discussed in this paper with full-scale studies, in order to confirm the validity of information in the literature. Testing of full-scale structural systems has several advantages listed in the following:

4) Since, as observed in several described tests, the local punching failure does not necessarily lead to the collapse of the structure, the redistribution of internal forces due to local punching failures needs to be studied in a real scale structural system.

5) Most studies considered reduced scaled structures. The behaviour at full-scale should be investigated to assess size effects.

6) Post-critical conditions need to be better understood in relation to integrity reinforcement. The tests examined show either explicitly or implicitly that the gravity loads could be supported by the membrane effect and the dowel action of longitudinal reinforcement, with bottom bars in each direction passing over the column (Fernández Ruiz et al., 2013).

7) There is only one study on complete building frames with shear reinforcement and there is the need of more results. The choice of the reinforcement types can have a consequence on the building response in terms of damage level and is related to costs.

\section{Slab STRESS - seismic testing of a R/C flat slab structure}

An international research project has been recently launched, with the main objective of improving the knowledge on the seismic response of reinforced concrete flat slab structures and propose design guidelines for the European and international standards. In the "Slab STRESS" research program (Slab STructural RESponse for Seismic design in Europe), flat slab floors in a full-scale flat slab frame will be tested under seismic and cyclic loading at the reaction wall facility of the Joint Research Centre (JRC) in the European Laboratory for Structural Assessment (ELSA) in Ispra, Italy. 
The response of a flat slab building designed as a secondary system will be experimentally tested. The primary system considered in the design consists of ductile walls designed following EN 1998-1. The overall geometry is shown in Fig.7.

In a first phase, pseudo-dynamic testing (Pinto et al. 2004) will be carried out for the seismic loading using a numerical model of the walls. The aim is to show that the flat slab frame can maintain the structural performance needed to carry the gravity loads.

In a second phase, cyclic loading will be carried out on the building to assess the ultimate drift capacity. The response of each slab-column connection will be measured using load cells embedded in the columns.

A number of choices made for this program relate to the analysis of the state of the art carried out in this paper. Above all the choice of a real scale test on a two-storey frame allows to consider the structural response with redistribution of load effects in the different types of connections with realistic boundary conditions. Compared to the specimens scaled to $30-50 \%$ in the literature, the full-scale specimen test aims also to assess size-effects. The gravity shear ratio for the seismic combination is equal to 0.4 , that is higher than most values in previous tests (see Table 3). This is related to a common practice in some European countries to use relatively high values of GSR. In addition this choice was related to findings by Pan and Moehle (1989), reporting that GSR $=0.4$ is the value below which interior connections without transverse reinforcement showed the development of some inelastic deformations under lateral loading before punching. Further choices related to the practice in Europe are the span to depth ratio $(\mathrm{L} / \mathrm{t}=22-25)$ and the column size in relation to the span (L/c ranging from 12.5 in the interior span to 15 in the corner span).

Results will be related also to the use of shear reinforcement, with welded studs provided in the second floor. This will extend the knowledge gathered in the tests examined in this paper. Moreover, after a first phase of cyclic loading, the first floor will be strengthened using postinstalled steel shear reinforcement, and then will be tested again.

\section{Summary and conclusions}

The state of the art of experimental research on reinforced concrete flat slab frame tests for gravity and lateral loading has been described. A brief review of test results on isolated slabcolumn connections was presented first; then a total of five studies and seven tests on single and multi-storey reinforced concrete flat slab frames were analysed.

The set of tests allowed a comparison between similar specimens, related to common and different features and parameters in the test.

Almost all tests on single and multi-storey reinforced concrete flat slab frames reported in the literature are on scaled specimens. Square and rectangular panels were investigated, with similar span-to-depth ratios and column sizes relative to slab span. The slab thickness in the scaled specimens is smaller than $100 \mathrm{~mm}$.

The design was carried out using mostly North American seismic regulations. The seismic designs of the prototype structures considered "non-participating" slabs with seismic resistant walls or frames, for three studies. The comparison showed better performance of the specimen designed for seismic actions. 
All tests showed a non-linear global response reaching ultimate drifts with a lower bound of $2.5 \%$ and up to $6 \%$. The gravity shear ratios were in most cases between 0.2 and 0.3 . The response is characterized by a progressive spreading of damage and a sequence of failures in the different connections.

One test was carried out for a full scale multi-storey specimen designed for gravity loads only and with a low gravity shear ratio. The test was stopped after the first connection failed. Hence the occurrence of the sequence of failures has not yet been confirmed for a full-scale structure.

All specimens designed for seismic actions had integrity reinforcement. The tests showed the efficiency of the integrity reinforcement since in all cases, the gravity loads could be carried after local punching of the slab-column connections. Nevertheless, this could also be due to the relatively low GSRs chosen for all tests.

Cyclic lateral loading compared to monotonic loading causes more damage, reducing ultimate drifts. More tests on biaxial loading are needed to show these effects in flat slab frames.

The main conclusions and research developments are the following:

- Floor tests show redistribution of internal forces and the combined structural actions of internal, edge and corner connections, up to drifts equal to or higher than those observed in isolated slab-column connections;

- Only one test studied a full-scale multi-storey frame; moreover, this specimen was designed for gravity loads only. In addition, the test was stopped at the first connection failure. More tests on full scale structures with lateral loads considered in the design are needed;

- Tests on isolated slab-column connections show failures and the related drifts approximating the boundary conditions; most tests have been carried out on internal connections. Hence more tests on flat slab frames are needed with internal, edge and corner joints;

- $\quad$ Most specimens were scaled from prototype structures designed with flat-slab frames combined with walls or beam-columns frames; the tests were conducted on the sole scaled flat-slab frame, without considering the interaction with the wall or beam/column frame response; tests considering the combined response with walls are needed, to understand the effectiveness of the design;

- $\quad$ Tests on flat slab frames with higher gravity shear ratios are needed;

- Tests carried out on full scale specimens thus accounting for size effect with common structural geometry are needed;

- $\quad$ Tests on flat slab frames considering shear reinforcement are needed.

Summing up, the research on scaled specimen considering design for lateral loading shows promising results for the seismic performance and design of flat-slab frames. Full-scale studies are needed to confirm and extend these results.

Based on these conclusions, a new research programme, regarding tests for seismic and cyclic loading on a real scale flat slab building was motivated.

Due the growing use of flat slab structures in Europe, there is a need for a greater and deeper knowledge of the behaviour of these elements as a part of the whole system of the building and for adequate provisions on flat slabs in the European standard for earthquake resistant buildings. 


\section{Acknowledgements}

The research was carried out in preparation of the SlabSTRESS experimental campaign, that is a part of the Transnational Access activities of the SERA (Seismology and Earthquake Engineering Research Infrastructure Alliance for Europe) project.

\section{References}

ACl Committee 318 (1983), "Building Code Requirements for Concrete (ACI 318-83)" American Concrete Institute, Farmington Hills, Mich., 1983, 111 pp.

$\mathrm{ACl}$ Committee 318 (2014) , "ACl Building Code Requirements for Structural Concrete (ACl 318-14) and Commentary (ACI 318R-14)," American Concrete Institute, Farmington Hills, MI, $519 \mathrm{pp}$.

ACl Committee 318 (2002), "Building Code Requirements for Structural Concrete (ACI 318-02) and Commentary (318R-02)," American Concrete Institute, Farmington Hills, Mich., 443 pp.

ACI-ASCE Committee 352. (1988). Recommendations for Design of Slab-Column Connections in Monolithic Reinforced Concrete Structures. ACl Structural Journal, 85, 6, 675-696.

ACl-ASCE Committee 421, (1999), "Shear Reinforcement for Slabs (ACI 421.1R-99)," American Concrete Institute, Farmington Hills, Mich., 15 pp.

ACI-ASCE Committee 421 (2010). Guide to Seismic Design of Punching Shear Reinforcement in Flat Plates, American Concrete Institute, Farmington Hills, Mich., 34 pp.

ACI-ASCE Committee 421 (2015). ACl 421.3R-15 Guide to Design of Reinforced Two-Way Slab System, American Concrete Institute, Farmington Hills, Mich., 28 pp.

Almeida, A. F. O., Ramos, A. P., Lucio, V., Marreiros, R. (2019). Behaviour of RC flat slabs with shear bolts under reversed horizontal cyclic loading. Structural concrete, 1-16. doi: https://doi.org/10.1002/suco.201900128

CEN. EN 1998-1. Eurocode 8: Design of structures for earthquake resistance - Part 1: General rules, seismic actions and rules for buildings. 2004

Dovich, L. M., \& Wight, J. L. (2005). Effective Slab Width Model for Seismic Analysis of Flat Slab Frames. ACl Structural Journal, 102, 6, 868-875.

Drakatos I.-S, Muttoni, A., Beyer, K. (2016). Internal slab-column connections under monotonic and cyclic imposed rotations. Engineering Structures, 123, 501-516, doi: https://doi.org/10.1016/j.engstruct.2016.05.038.

Drakatos I.-S, Muttoni, A., Beyer, K. (2018). Mechanical Model for Drift-Induced Punching of Slab-Column Connections without Transverse Reinforcement. ACI Structural Journal, 115, 2, 463-474.

Einpaul J., Fernández Ruiz M., Muttoni A. (2015). Influence of moment redistribution and compressive membrane action on punching strength of flat slabs. Engineering Structures, 86, 43-57 
Einpaul J., Ospina C. E., Fernández Ruiz M., Muttoni A. (2016). Punching Shear Capacity of Continuous Slabs. ACl, Structural Journal, 113, 4, 861-872.

Fardis, M., N. (2009) Seismic Design, Assessment and Retrofitting of Concrete Buildings based on EN-Eurocode 8. Springer.

Fernández Ruiz, M., Mirzaei, Y., Muttoni, A. (2013). Post-Punching behaviour of flat slab. ACl structural Journal, 110, 5, 801-812.

Fick, D. R., Sozen, M. A., Kreger, M. E. (2017). Response of Full-Scale Three-Story Flat-Plate Test Structure to Cycleas of Increasing Lateral Load. ACl Structural Journal, 114, 6, 1507-1518.

Hawkins, N. M., and Mitchell, D. (1979). Progressive Collapse of Flat Plate Structures. ACI Journal, Proceedings, 76, 7, 775-808.

Hwang, S.-J., Moehle, J. P. (1993). An Experimental Study of Flat-Plate Structures under Vertical and Lateral Loads. Report N. UCB/EERC-93/03, Earthquake Engineering Research Center, University of California, Barkeley.

Hwang, S.-J., Moehle, J. P. (2000). Vertical and Lateral Laod Tests of Nine-Panel Flat-Plate Frame. ACl Structural Journal, 97, 1, 193-203.

Hueste, M. B. D., Browning, J., Lepage, A., Wallace, J., W. (2007). Seismic Design Criteria for Slab-column Connections. ACl Structural Journal, 104, 4, 448-458.

Kang, T. H.-K. \& Wallace, J. W. (2004). Shake Table Tests of Reinforced Concrete Flat Plate Frames and Post-Tensioned Flat Plate Frames. $13^{\text {th }}$ World Conference on Earthquake Engineering, Vancouver, B.C., Canada. 1119.

Kang, T. H.-K. \& Wallace, J. W. (2005). Dynamic Response of Flat Plate System with Shear Reinforcement. ACI Structural Journal, 102, 5, 763-773.

Kang, T. H.-K. \& Wallace, J. W. (2006). Dynamic Tests and Modelling of RC and PT SlabColumn Connections. Proceedings of the $8^{\text {th }}$ U.S. National Conference on Earthquake Engineering, San Francisco, Calif., Paper 0362, 10 pp. (Cd-rom).

Megally, S. \& Ghali, A. (2000). Seismic behaviour of slab-column connections. Canadian Journal of Civil Engineering, 27 (1), 84-100.

Moehle J. P., Diebold J. W. (1984). Experimental Study of the Seismic Response of a TwoStory of a Flat-Plate Structure. University of California, Berkeley.

Muttoni, A., (2008). Punching shear strength of reinforced concrete slabs without transverse reinforcement, ACl Structural Journal, 105, 4,440-450.

Pan, A. \& Moehle, J. P. (1987). Lateral Displacement Ductility of Reinforced Concrete Flat Plates. ACl Structural Journal, 86, 3, 250-258.

Pan, A. \& Moehle, J. P. (1989). Lateral displacement ductility of reinforced concrete flat plates. ACI Structural Journal, 86, 250-258. doi: 10.14359/2889.

Park, R., \& Gamble, W. L. (2000). Reinforced Concrete Slab. $2^{\text {nd }}$ edition. John Wiley \& Sons, Inc.

Pinto, A.V., Pegon, P., Magonette, G., and Tsionis G. (2004). Pseudodynamic testing of bridges using non-linear substructuring. Earthquake Engineering and Structural Dynamics 33, 11, $1125-1146$. 
Rha, C., Kang, T. H.-K., Shin, M., Yoon, J. B. (2014). Gravity and Lateral Load-Carrying Capacities of Reinforced Concrete Flat Plate Systems. ACl Structural Journal, 111, 4, 753-764.

Robertson, I. N., Kawai, T., Lee, J., Enemoto, B. (2002). Cycling Testing of Slab-Column Connections with Shear Reinforcement. ACl Structural Journal, 99, 5, 605-613.

Setiawan, A., Vollum, R. L., Macorini, L. (2019). Numerical and analytical investigation of internal slab-column connections subjected to cyclic loading. Engineering structures, 184, 535554.

Tian, Y., Jirsa, J. O., Bayrak, O. (2008). Strength evaluation of interior slab-column connections. ACl Structural Journal, 105(6), 692-700.

International Conference of Building Officials (1982) Uniform Building Code, 780 pp. 
Table 1 Description of the tests

\begin{tabular}{|l|c|c|c|c|c|}
\hline Author & Lateral Loading type & Scale & $\begin{array}{c}\text { Nr. of } \\
\text { floors }\end{array}$ & $\begin{array}{c}\text { Nr. of } \\
\text { specimens }\end{array}$ & $\begin{array}{c}\text { Transv. } \\
\text { Reinf. }\end{array}$ \\
\hline $\begin{array}{l}\text { Hwang and } \\
\text { Moehle }\end{array}$ & $\begin{array}{c}\text { Cyclic quasi-static } \\
\text { biaxial }\end{array}$ & $40 \%$ & 1 & 1 & - \\
\hline Rha et al. & $\begin{array}{c}\text { Cyclic / Monotonic } \\
\text { quasi-static }\end{array}$ & $50 \%$ & 1 & 3 & - \\
\hline Fick et al & Cyclic quasi-static & $100 \%$ & 3 & 1 & - \\
\hline $\begin{array}{l}\text { Moehle and } \\
\text { Diebold }\end{array}$ & Shake Table & $30 \%$ & 2 & 2 & Strirrups \\
\hline $\begin{array}{l}\text { Kang and } \\
\text { Wallace }\end{array}$ & Shake table & $30 \%$ & 2 & 2 & \\
\hline
\end{tabular}

Table 2 Test specimens geometry

\begin{tabular}{|l|c|c|c|c|c|c|c|c|c|c|}
\hline \multicolumn{1}{|c|}{ Author } & $\begin{array}{c}\text { span L } \\
(\mathrm{m})\end{array}$ & $\begin{array}{c}\text { span } \mathrm{L}^{\prime} \\
(\mathrm{m})\end{array}$ & $\begin{array}{c}\text { span } \\
\mathrm{nr}\end{array}$ & $\begin{array}{c}\text { overhang } \\
(\mathrm{m})\end{array}$ & $\begin{array}{c}\text { slab } \\
\text { thickness } \\
\mathrm{t}(\mathrm{mm})\end{array}$ & $\mathrm{L} / \mathrm{t}$ & $\mathrm{L}^{\prime} / \mathrm{t}$ & $\begin{array}{c}\text { internal } \\
\text { column c } \\
(\mathrm{m})\end{array}$ & $\begin{array}{c}\text { lateral, } \\
\text { corner } \\
\text { column } \mathrm{c}^{\prime} \\
(\mathrm{m})\end{array}$ & $\mathrm{L} / \mathrm{c}$ \\
\hline Hwang and Moehle & 2.7 & 1.8 & $3 \times 3$ & & 81 & 33 & 23 & $0.24\left(^{*}\right)$ & 0.16 & 11.3 \\
\hline Rha et al. & 2.75 & 1.65 & $2 \times 2$ & & 90 & 31 & 18 & 0.25 & 0.25 & 11.0 \\
\hline Fick et al & 6.1 & 6.1 & $2 \times 1$ & $1.5,1.5$ & 180 & 34 & & 0.46 & 0.46 & 13.3 \\
\hline Moehle and Diebold & 1.83 & 1.83 & $3 \times 1$ & 0.9 & 61 & 30 & & 0.14 & 0.14 & 13.1 \\
\hline Kang Wallace & 2.06 & 2.06 & $2 \times 1$ & 0.9 & 89 & 23 & & 0.2 & 0.2 & 10.3 \\
\hline
\end{tabular}

Note: $\left({ }^{*}\right)$ in addition half of the columns were rectangular with similar total cross section 
Table 3 Gravity Shear Ratio (GSR) calculation for test specimens

\begin{tabular}{|c|c|c|c|c|c|c|c|c|c|c|c|c|c|c|c|c|}
\hline & & \begin{tabular}{|c|} 
tributary \\
length 1 \\
$(\mathrm{~m})$
\end{tabular} & $\begin{array}{l}\text { tributary } \\
\text { length } 2 \\
(\mathrm{~m})\end{array}$ & $\begin{array}{c}\text { Added } \\
\text { load } \\
(\mathrm{kN} / \mathrm{m} 2)\end{array}$ & $\begin{array}{c}\text { Self } \\
\text { weight } \\
(\mathrm{kN} / \mathrm{m} 2)\end{array}$ & $\begin{array}{c}\text { Total } \\
\text { load } \\
(\mathrm{kN} / \mathrm{m} 2)\end{array}$ & $\begin{array}{c}\text { coeff. } \\
(-)\end{array}$ & $\begin{array}{c}\mathrm{Vg} \\
(\mathrm{kN})\end{array}$ & $\begin{array}{c}\mathrm{c} \\
(\mathrm{mm})\end{array}$ & $\begin{array}{c}\mathrm{d} \\
(\mathrm{mm})\end{array}$ & $\begin{array}{c}\mathrm{fc} \\
(\mathrm{MPa})\end{array}$ & $\begin{array}{c}\text { Vo } \\
(\mathrm{kN})\end{array}$ & $\begin{array}{c}\text { Vg Test } \\
\text { (KN) }\end{array}$ & $\begin{array}{c}\text { Vg Test/ } \\
\text { Vg }\end{array}$ & $\begin{array}{c}\text { GSR } \\
\text { (Vg / Vo) }\end{array}$ & $\begin{array}{c}\text { GSR } \\
\text { (Auhors) }\end{array}$ \\
\hline \multirow{3}{*}{$\begin{array}{l}\text { Hwang } \\
\text { Moehle }\end{array}$} & internal & 2.74 & 1.83 & 5.8 & 2.0 & 7.8 & 1.10 & 42 & 244 & 69 & 21 & 131 & 33.40 & 0.79 & 0.32 & 0.30 \\
\hline & lateral & 1.35 & 1.83 & 5.8 & 7.8 & 7.8 & 0.93 & 18 & 160 & 69 & 21 & 65 & 13.35 & 0.76 & 0.27 & \\
\hline & corner & 1.35 & 0.90 & 5.8 & 7.8 & 7.8 & 0.90 & 8 & 160 & 69 & 21 & 41 & 5.79 & 0.69 & 0.20 & \\
\hline \multirow[t]{2}{*}{ Rha et al. } & internal & 2.75 & 1.65 & 9.0 & 2.3 & 11.3 & 1.25 & 63 & 250 & 70 & 26 & 152 & 61.20 & 0.97 & 0.41 & 0.44 \\
\hline & lateral & 1.5 & 1.65 & 9.0 & 2.3 & 11.3 & 0.93 & 25 & 250 & 70 & 26 & 106 & 27.50 & 1.10 & 0.24 & 0.28 \\
\hline \multirow[t]{2}{*}{ Fick et al. } & internal & 6.10 & 4.58 & 0.6 & 4.5 & 5.1 & 1.10 & 157 & 460 & 152 & 25 & 623 & & & 0.25 & 0.21 \\
\hline & lateral & 4.58 & 4.58 & 0.6 & 4.5 & 5.1 & 0.93 & 99 & 460 & 152 & 25 & 623 & & & 0.16 & \\
\hline $\begin{array}{l}\text { Moehle } \\
\text { Diebold }\end{array}$ & internal & 1.83 & 1.83 & 3.4 & 1.5 & 4.9 & 1.10 & 18 & 137 & 54 & 28 & 72 & & & 0.25 & \\
\hline \multirow{2}{*}{$\begin{array}{c}\text { Kang } \\
\text { Wallace }\end{array}$} & internal & 2.10 & 2.10 & 5.7 & 2.2 & 7.9 & 1.10 & 38 & 203 & 70 & 28 & 134 & & & 0.28 & 0.25 \\
\hline & lateral & 1.15 & 2.10 & 5.7 & 2.2 & 7.9 & 0.93 & 17 & 203 & 70 & 28 & 92 & & & 0.19 & 0.20 \\
\hline
\end{tabular}

LEGEND: Tributary lengths = calculated with half centre to centre spans, adding half column for side and corners spans; coeff. = coefficients for $V_{g}$ transfer to the columns (from practice); $V g=$ calculated value $=$ Total load $x$ tributary area $\times$ coefficient; $V g$ Test $=$ measured gravity shear; $V_{o}=1 / 3 f_{c}{ }^{1 / 2} \times($ perimeter at $d / 2) \times d ; G S R=V_{g} / V_{o}$ (calculated value) ; GSR (Authors) = value reported in the literature

Table 4 - Geometries of the prototype structures and scale of the test specimens

\begin{tabular}{|c|c|c|c|c|c|c|c|c|c|}
\hline Author & $\begin{array}{c}\text { spans } \\
(\mathrm{m})\end{array}$ & span $\mathrm{nr}$ & $\begin{array}{l}\text { overhang } \\
(\mathrm{m})\end{array}$ & $\begin{array}{c}\text { Slab depth } \\
\mathrm{h}(\mathrm{m})\end{array}$ & $\mathrm{L}_{\max } / \mathrm{h}$ & $L_{\min } / \mathrm{h}$ & $\begin{array}{c}\text { column c } \\
(\mathrm{m})\end{array}$ & L/C & $\begin{array}{c}\text { Scale of the } \\
\text { specimen }\end{array}$ \\
\hline $\begin{array}{l}\text { Hwang } \\
\text { Moehle }\end{array}$ & $\begin{array}{c}6.90 x \\
4.60\end{array}$ & $3 \times 3$ & - & 0.20 & 35 & 23 & 0.61 & 11.3 & $4 / 10$ \\
\hline $\begin{array}{l}\text { Rha et } \\
\text { al. }\end{array}$ & $\begin{array}{c}5.50 x \\
3.30\end{array}$ & $2 \times 2$ & - & 0.18 & 31 & 18 & 0.50 & 11.0 & $\approx 1 / 2$ \\
\hline Fick et al & $\begin{array}{c}6.10 x \\
6.10\end{array}$ & $2 \times 1$ & 1.40 & 0.18 & 34 & & 0.46 & 13.3 & Full-scale \\
\hline $\begin{array}{l}\text { Moehle } \\
\text { Diebold }\end{array}$ & $\begin{array}{c}6.10 x \\
6.10\end{array}$ & $3 \times 1$ & 0.90 & 0.20 & 30 & & 0.45 & 13.6 & $3 / 10$ \\
\hline $\begin{array}{l}\text { Kang } \\
\text { Wallace }\end{array}$ & $\begin{array}{c}6.10 x \\
6.10\end{array}$ & $2 \times 1$ & 0.90 & 0.27 & 23 & & 0.60 & 10.2 & $\approx 1 / 3$ \\
\hline
\end{tabular}


Table 5 Design of prototype structures

\begin{tabular}{|l|l|l|l|}
\hline Author & Design & Type of frame $\left(^{*}\right)$ & Design notes \\
\hline $\begin{array}{l}\text { Hwang and } \\
\text { Moehle }\end{array}$ & $\begin{array}{l}\text { ACl 318-83, Prototype } \\
\text { Structure high rise-building } \\
\text { with secondary slabs, wind } \\
\text { and seismic load effects } \\
\text { calculated }\end{array}$ & Secondary & Different column sections \\
\hline Rha et al. & Not specified & & $\begin{array}{l}\text { Different reinforcement } \\
\text { arrangements (3 } \\
\text { specimens) }\end{array}$ \\
\hline Fick et al & $\begin{array}{l}\text { Gravity Design - Direct } \\
\text { Method ACl 318 (2002) }\end{array}$ & $\begin{array}{l}\text { Gravity load design, } \\
\text { without lateral load } \\
\text { resisting elements }\end{array}$ & Primary \\
\hline $\begin{array}{l}\text { Moehle and } \\
\text { Diebold }\end{array}$ & $\begin{array}{l}\text { Prototype Structure Primary } \\
\text { slab frame for Zone 2 UBC } \\
\text { 1982 and ACl 318-03 }\end{array}$ & $\begin{array}{l}\text { Spandrel beams } \\
\text { transverse to lateral } \\
\text { actions. } \\
\text { Load combinations results } \\
\text { show that gravity shears } \\
\text { and moments dominate. } \\
\text { Strong columns relative to } \\
\text { slab. }\end{array}$ \\
\hline $\begin{array}{l}\text { Kang and } \\
\text { Wallace }\end{array}$ & $\begin{array}{l}\text { Secondary slab frames for } \\
\text { buildings with primary walls or } \\
\text { frames, ACl 318-02, Zone 4 } \\
\text { (high) seismic region }\end{array}$ & $\begin{array}{l}\text { Non-participating for high } \\
\text { seismic risk regions / } \\
\text { intermediate frames in } \\
\text { moderate seismic regions }\end{array}$ & $\begin{array}{l}\text { Longitudinal } \\
\text { reinforcement yield before } \\
\text { punch. } \\
\text { Strong columns relative to } \\
\text { slab. } \\
\text { Shear failure within shear } \\
\text { reinforced zone. }\end{array}$ \\
\hline
\end{tabular}

Table 7 Longitudinal reinforcement ratios

\begin{tabular}{|c|c|c|c|}
\hline Author & $\begin{array}{c}\text { col. strip } \\
\text { top }\end{array}$ & $\begin{array}{c}\text { central c+3h, } \\
\text { col. strip, top }\end{array}$ & $\begin{array}{c}\text { mid. } \\
\text { Strip, } \\
\text { bottom }\end{array}$ \\
\hline Hwang Moehle & $0.75 \%$ & & $0.27 \%$ \\
\hline Rha et al. & $1 \%$ & $1.20 \%$ & $0.38 \%$ \\
\hline Fick et al. & $0.50 \%$ & & $0.25 \%$ \\
\hline Moehle and Diebold & $1.00 \%$ & $1.10 \%$ & $0.36 \%$ \\
\hline Kang and Wallace & $1 \%$ & $1.40 \%$ & $0.45 \%$ \\
\hline
\end{tabular}


Table 8 Measurements

\begin{tabular}{|c|c|c|c|c|}
\hline Author & $\begin{array}{l}\text { Measurement } \\
\text { Global }\end{array}$ & Member forces & Local deformations & $\begin{array}{l}\text { Damage } \\
\text { observation }\end{array}$ \\
\hline $\begin{array}{l}\text { Hwang } \\
\text { Moehle }\end{array}$ & $\begin{array}{l}\text { Force- } \\
\text { displacement }\end{array}$ & $\begin{array}{l}\text { Column base forces (3 } \\
\text { components). } \\
\text { Slab moment transfer } \\
\text { Slab vertical } \\
\text { deflections. } \\
\text { Slab column rotations }\end{array}$ & $\begin{array}{l}\text { Slab reinforcement (slab } \\
\text { moment transfer) }\end{array}$ & \\
\hline $\begin{array}{l}\text { Rha et } \\
\text { al. }\end{array}$ & $\begin{array}{l}\text { Force- } \\
\text { displacement }\end{array}$ & $\begin{array}{l}\text { Column base vertical } \\
\text { reaction and top lateral } \\
\text { force }\end{array}$ & & \\
\hline $\begin{array}{l}\text { Fick et } \\
\text { al }\end{array}$ & $\begin{array}{l}\text { Force- } \\
\text { displacement } \\
\text { at three levels }\end{array}$ & - & & \\
\hline $\begin{array}{l}\text { Moehle } \\
\text { Diebold }\end{array}$ & $\begin{array}{l}\text { Floor } \\
\text { displacements, } \\
\text { horizontal and } \\
\text { vertical } \\
\text { accelerations }\end{array}$ & $\begin{array}{l}\text { Shear and moment } \\
\text { below footings }\end{array}$ & $\begin{array}{l}\text { Column and slab average } \\
\text { deformations (near to } \\
\text { connections) reinforcement } \\
\text { strains. }\end{array}$ & \\
\hline $\begin{array}{l}\text { Kang } \\
\text { Wallace }\end{array}$ & $\begin{array}{l}\text { Floor and } \\
\text { footing } \\
\text { displacements } \\
\text { and } \\
\text { accelearions }\end{array}$ & $\begin{array}{l}\text { Column and slab } \\
\text { moment-curvature }\end{array}$ & $\begin{array}{l}\text { Slab and column average } \\
\text { deformations. Transverse } \\
\text { reinforcement strains. }\end{array}$ & \\
\hline
\end{tabular}

